\title{
Composition and diversity of anurans in the Restinga of the Conde municipality, northern coast of the state of Bahia, northeastern Brazil
}

\author{
Felipe Augusto Trindade Gondim-Silva ${ }^{1}$, Alessandra Rodrigues Santos Andrade ${ }^{2}$, Rafael Oliveira Abreu ${ }^{1}$,
} Jamile Santos Nascimento ${ }^{1}$, Geovane Paixão Corrêa ${ }^{I}$, Lucas Menezes ${ }^{I}$, Camila Costa Trevisan ${ }^{1}$, Soraia Silva Camargo $^{1}$ \& Marcelo Felgueiras Napoli ${ }^{1,3}$

${ }^{1}$ Universidade Federal da Bahia, Instituto de Biologia, Departamento de Zoologia, Salvador, BA, Brazil

${ }^{2}$ Universidade Federal da Bahia, Instituto de Biologia, Programa de Pós-Graduação em Ecologia e Biomonitoramento, Salvador, BA, Brazil

${ }^{3}$ Corresponding author: Marcelo Felgueiras Napoli, e-mail: napoli@ufba.br

GONDIM-SILVA F.A.T., ANDRADE, A.R.S., ABREU, R.O., NASCIMENTO, J.S., CORRÊA, G.P., MENEZES, L., TREVISAN, C.C., CAMARGO, S.S., NAPOLI, M.F. Composition and diversity of anurans in the Restinga of the Conde municipality, northern coast of the state of Bahia, northeastern Brazil. Biota Neotropica. 16(3): e20160157. http://dx.doi.org/10.1590/1676-0611-BN-2016-0157

\begin{abstract}
The Conde municipality is located in the northern coast of the state of Bahia (NC), northeastern Brazil, and is part of the Atlantic Tropical domain. The anuran fauna of the northern portion of the NC is still poorly known if compared to the southern portion. The Restinga is one of the predominant environments of the coastal plains of the NC and it is characterized essentially by presenting sandy soil covered by herbaceous and shrubby vegetation. The objective of this study was to determine the anuran species composition and diversity for the Restinga of the Conde municipality. Sampling was carried out at night by active search over four periods of five consecutive days each, two over the 'main rainy season' and two in a 'lesser rainy season', using 14 sample units (SUs) and five extra sample plots (EPs). We calculated dominance and species diversity using the Berger-Parker and Shannon-Wiener H' indices, respectively. We used accumulation curves and the Jackknife 1 estimator to estimate anuran species richness, considering only the data obtained from the SUs. We recorded 713 anuran specimens distributed within 33 species, 13 genera and five families (Bufonidae, Craugastoridae, Hylidae, Leptodactylidae and Microhylidae). The Hylidae and Leptodactylidae families had the highest species richness. Considering only the SUs (Jackknife 1 estimator in brackets), we recorded 28 species in the study area (33.9 \pm 2.3$), 13$ in Shrubby Vegetation Zones - SVZ $(20.8 \pm 2.9)$ and 25 in Freshwater Wetland Zones - FWZ (28.9 \pm 1.9$)$. The abundance and species diversity of the FWZ $\left(n=638\right.$ specimens; $\left.H^{\prime}=2.4\right)$ were higher than those recorded for the $\mathrm{SVZ}(\mathrm{n}=52$ specimens; H' = 1.9). The SVZ and FWZ showed distinct dominant species, wherein Pristimantis paulodutrai was the dominant species in SVZ and Scinax fuscomarginatus in FWZ. The Restinga of the Conde municipality stands out as the one with the highest anuran species richness already recorded considering only SVZ and FWZ. Moreover, its anuran species composition represented 55\% of the anuran species known for the NC and included taxa common to three different morphoclimatic domains (Tropical Atlantic, Cerrado and Caatinga).
\end{abstract}

Keywords: inventory, species richness, wetland zones, shrubby vegetation zones, coastal plains.

GONDIM-SILVA F.A.T., ANDRADE, A.R.S., ABREU, R.O., NASCIMENTO, J.S., CORRÊA, G.P., MENEZES, L., TREVISAN, C.C., CAMARGO, S.S., NAPOLI, M.F. Composição e diversidade de anuros na Restinga do município de Conde, litoral norte do estado da Bahia, nordeste do Brasil. Biota Neotropica. 16(3): e20160157. http://dx.doi.org/10.1590/1676-0611-BN-2016-0157

Resumo: O município de Conde situa-se no litoral norte do estado da Bahia (LN), nordeste do Brasil, e está inserido no domínio Tropical Atlântico. A fauna de anuros da porção setentrional do LN ainda é pouco conhecida se comparada à porção sul. A Restinga é um dos ambientes predominantes das planícies costeiras do LN, sendo caracterizada essencialmente por apresentar solo arenoso e vegetação herbácea e arbustiva. O objetivo deste estudo foi determinar a composição e a diversidade de espécies de anuros da Restinga do município de Conde. A amostragem foi realizada por procura ativa noturna, durante quatro períodos de cinco dias consecutivos cada, 
dois na estação 'mais chuvosa' e dois em estação 'menos chuvosa', utilizando-se 14 unidades amostrais (UAs) e cinco pontos amostrais extras (PEs). Calculamos a dominância e a diversidade de espécies utilizando os índices de Berger-Parker e de Shannon-Wiener-H'. Utilizamos curvas de acumulação de espécies e o estimador Jackknife 1 para estimar a riqueza de espécies de anuros, considerando-se somente os dados obtidos nas UAs. Registramos 713 espécimes de anuros distribuídos em 33 espécies, 13 gêneros e cinco famílias (Bufonidae, Craugastoridae, Hylidae, Leptodactylidae e Microhylidae). As famílias Hylidae e Leptodactylidae apresentaram as maiores riquezas de espécies. Considerando-se somente UAs (estimador Jackknife 1 entre parêntesis) foram registradas 28 espécies na área de estudo $(33,9 \pm 2,3), 13$ nas zonas de moitas $(20,8 \pm 2,9)$ e 25 nas zonas úmidas $(28,9 \pm 1,9)$. A abundância e a diversidade de espécies para as zonas úmidas $\left(n=638\right.$ espécimes; $\left.H^{\prime}=2,4\right)$ foram superiores às registradas para as zonas de moitas $\left(\mathrm{n}=52\right.$ espécimes; $\left.\mathrm{H}^{\prime}=1,9\right)$. As zonas de moitas e úmidas exibiram espécies dominantes distintas, sendo Pristimantis paulodutrai a espécie dominante para as zonas de moitas e Scinax fuscomarginatus para as zonas úmidas. A Restinga do município de Conde desponta como aquela de maior riqueza de espécies de anuros já registrada considerando-se somente zonas de moitas e zonas úmidas. Além disso, sua composição de espécies de anuros representou 55\% do total de espécies de anuros conhecidas para o LN e incluiu táxons comuns a três diferentes domínios morfoclimáticos (Tropical Atlântico, Cerrado e Caatinga).

Palavras-chave: inventário, riqueza de espécies, zonas úmidas, zonas de moitas, planícies costeiras.

\section{Introduction}

The northern coast of the state of Bahia (NC) is part of the Tropical Atlantic Domain (Ab'Sáber 1977) and is essentially covered by the Atlantic Forest, a global biodiversity hotspot (Myers et al. 2000). The Restinga is one of the environments that shape this domain and is continuously distributed along the $200 \mathrm{~km}$ of coastal plains of the NC. This is a Quaternary habitat, characterized by sandy soils with high salt concentration, and covered predominantly by herbaceous and shrubby xerophytic vegetation under direct sunlight, the 'open Restinga' of Xavier et al. (2015).

The fauna and flora of the Restingas may represent a mosaic of species coming from adjacent and contiguous ecosystems, such as the Atlantic Forest (e.g., Freire 1990; Araújo 1992; Carvalho-e-Silva et al. 2000). Concerning the Restingas of northeastern Brazil, Xavier et al. (2015) identified them as a biotic element of distinct nature regarding ecological and biogeographical distribution of the anuran fauna, including species from three distinct morphoclimatic domains (Cerrado, Caatinga and Tropical Atlantic domains), which is of great importance because almost all previously known natural biogeographical units in northeastern Brazil were related to forested environments. Although presenting singular biogeographical importance, the $\mathrm{NC}$ is under pronounced degradation of its natural areas due to human activities such as agriculture, forestry and tourism (INEMA 2015), mainly after the construction of the highway BA-099 that has led to the progressive conversion of Restingas into resort areas (Bastazini et al. 2007). Furthermore, the faunistic information available in the literature for the $\mathrm{NC}$ is concentrated in its southern portion and is derived from occasional and specific studies on certain themes of interest to researchers, many of them not formally published (M.F. Napoli, unpublished data). This is also the case for the amphibian fauna, for which studies are concentrated in its southern portion and emphasizing forest patches in the Mata de São João municipality (e.g., Juncá 2006, Bastazini et al. 2007, Dabés et al. 2012). Indeed, the amphibians of the northern limit of the $\mathrm{NC}$ are represented in herpetological collections mainly by specimens obtained from sporadic and occasional inventories, which points to the urgency in the development of faunistic and ecologic studies for the region. The lack of information about amphibians in their natural environments hinders conservation actions (Rocha et al. 2008), as is the case for the Restingas of the NC.

The aim of this study is to determine the composition and diversity (richness, dominance and relative abundance of species) of the anuran species in the Restinga of the Conde municipality, northern coast of the state of Bahia, northeastern Brazil, considering both shrubby vegetation and freshwater wetland zones.

\section{Material and Methods}

\section{Study Area}

The study was carried out in the Conde municipality, northern coast of the state of Bahia (NC), northeastern Brazil (Figure 1). The $\mathrm{NC}$ is bordered by the municipalities of Salvador and Lauro de Freitas to the south and by the municipality of Rio Real to the north. Along its length there are state environmental protection areas (APAs), but no full conservation units of integral protection. The APA of the North Coast of the state of Bahia -APA NC ("APA do Litoral Norte do Estado da Bahia"; State Decree number 1,046 of 17 March 1992) has the greatest extent (ca. $10 \mathrm{~km}$ wide and $200 \mathrm{~km}$ long) and covers, from south to north, the municipalities of Mata de São João, Entre Rios, Esplanada, Conde (the study area) and Jandaíra. The main environmental conflicts in the APA of NC are, currently, the disorderly land use, lack of basic sanitation, substitution of natural areas by Pinus and Eucalyptus plantations, indiscriminate intensification of cattle raising, overfishing, degradation of mangroves and predatory tourism in coastal districts (INEMA 2015). The municipalities of Esplanada, Conde and Jandaíra were considered by Silva et al. (2008) as those with the most conserved areas in the NC due to their smaller degrees of urbanization.

The Conde municipality covers a total area of approximately $965 \mathrm{~km}^{2}$ (SEI 2015) and presents the widest coastal plain $\left(314 \mathrm{~km}^{2}\right)$ of the northern coast of the state of Bahia (Esquivel 2006). This municipality is bordered to the north by the Jandaíra municipality, to the west by the Rio Real municipality, to the south by the Esplanada municipality and to the east by the Atlantic Ocean. The climate is 


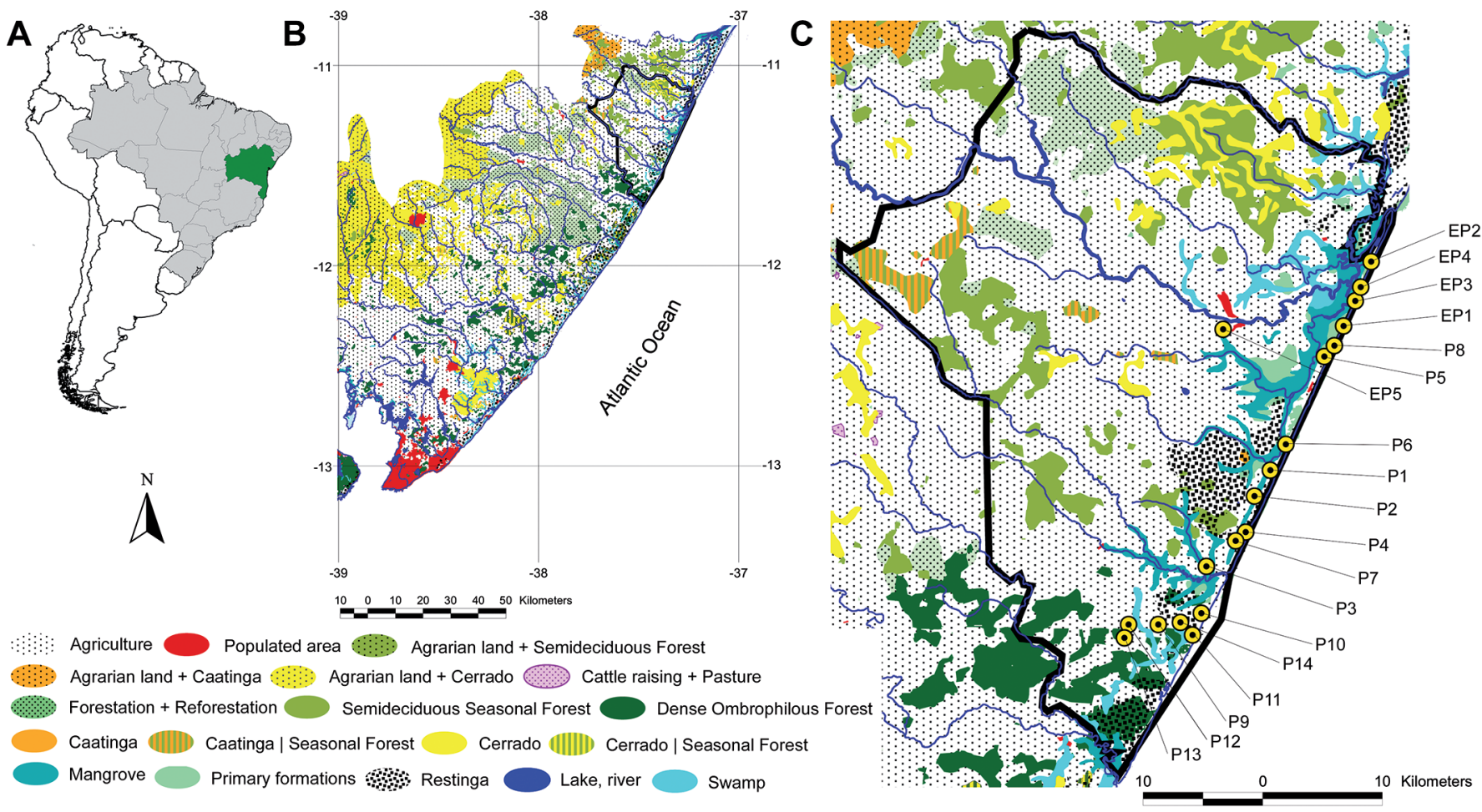

Figure 1. Distribution map of 14 sample units (SUs) and five extra sample plots (EPs) within the limits of the Conde municipality, northern coast of the state of Bahia, northeastern Brazil. (A) South America, Brazil in grey; (B) vegetation and hydrographic features of the northeastern state of Bahia, featuring the Conde municipality; (C) polygon of the Conde municipality, highlighting its vegetation, wetlands, Restingas, main types of anthropization, samples units (P1-P14) and extra sample plots (EP1-EP5). SUs/EPs from freshwater wetland zones, P4-P7, P12-P14, EP5. SUs/EPs from shrubby vegetation zones, P1-P3, P8-11, EP1-EP4.

classified by the Köppen climatic classification system as Tropical without dry season (Af). The average monthly temperature varies from $23^{\circ} \mathrm{C}$ to $27^{\circ} \mathrm{C}$ and the monthly rainfall from 61 to $264 \mathrm{~mm}$, with more intense rainfall from April to July (Alvares et al. 2013).

The NC coastal plains are characterized as valleys partially filled with sandy deposits of marine and continental origins, in association with climate changes and marine transgressions and regressions during the Quaternary (Soares \& Dominguez 2012). The sampled area studied herein was positioned alongside the coastline on areas of Holocene and Pleistocene deposits known as marine terraces (see Dominguez et al. 1999, Esquivel 2006, Nogueira 2006 and Bittencourt 2010 for geological-geomorphological descriptions and maps). Wetlands of a mosaic of shapes and sizes occur in the lowlands between these deposits, also present in the inland valleys associated with the Barreiras Formation of Tertiary age (Coastal Tablelands). This landscape holds a mosaic of different types of ecosystems, such as Restingas, wetlands (marshes and swamps), mangroves, dunes and riparian and ombrophilous forests (Esquivel 2006). Among them, we identified within the Restinga environment two main categories of physiognomies that could potentially be considered anuran habitats: shrubby vegetation zones and freshwater wetland zones (Figure 2). The shrubby vegetation zones (SVZ) were characterized by the presence of sandy soil covered by shrub and herbaceous vegetation, absence of water bodies, with or without terrestrial tank bromeliads. This physiognomy is equivalent to the 'shrub vegetation at the beach zone' of Bastazini et al. (2007) and to the 'Restinga em Moitas' of Menezes et al. (2009). The freshwater wetland zones (FWZ) are characterized by the presence of permanent or temporary freshwater bodies, with or without herbaceous and shrub vegetation on its margins. The wetlands sampled herein correspond to the freshwater marshes of Esquivel (2006) and Nogueira (2006), habitats dominated by herbaceous rather than woody plant species.

\section{Research Design and Field Methods}

For each physiognomy (SVZ and FWZ) we selected seven areas separated from one another by at least one kilometer to minimize biases due to pseudoreplication (Hurlbert 1984). In each sampling area a sample unit was established (SUs or Plots: SVZ P1-P3, P8-P11; FWZ $\mathrm{P} 4-\mathrm{P} 7, \mathrm{P} 12-\mathrm{P} 14)$, totaling 14 SUs measuring $60 \times 25 \mathrm{~m}$ each. In addition to these SUs, other five extra sample plots (EPs) were surveyed for anurans to complement the species inventory, four of them (EP1-EP4) located on the northernmost frontal dune near the Itapicuru river mouth and one located near the city of Conde (EP5). These extra sampling areas were not considered in the statistical analyses because they did not receive the same sampling effort designed for the SUs. Geographical coordinates of the SUs and EPs are in Table 1.

We sampled SUs in four periods of five consecutive days each: two periods over the main rainy season (15 to 21 May and 17 to 23 July 2015 ) and two in a lesser rainy period (10 to 16 September and 12 to 17 November 2015). To control for temporal biases in the characterization of the SUs, during each field campaign we distributed $50 \%$ of the SUs into shrubby vegetation zones and the other $50 \%$ into freshwater wetland zones. In the first and third sampling periods we sampled four SUs per physiognomy (P1-P8) and on the second and fourth sampling periods three SUs per physiognomy (P9-P14). 

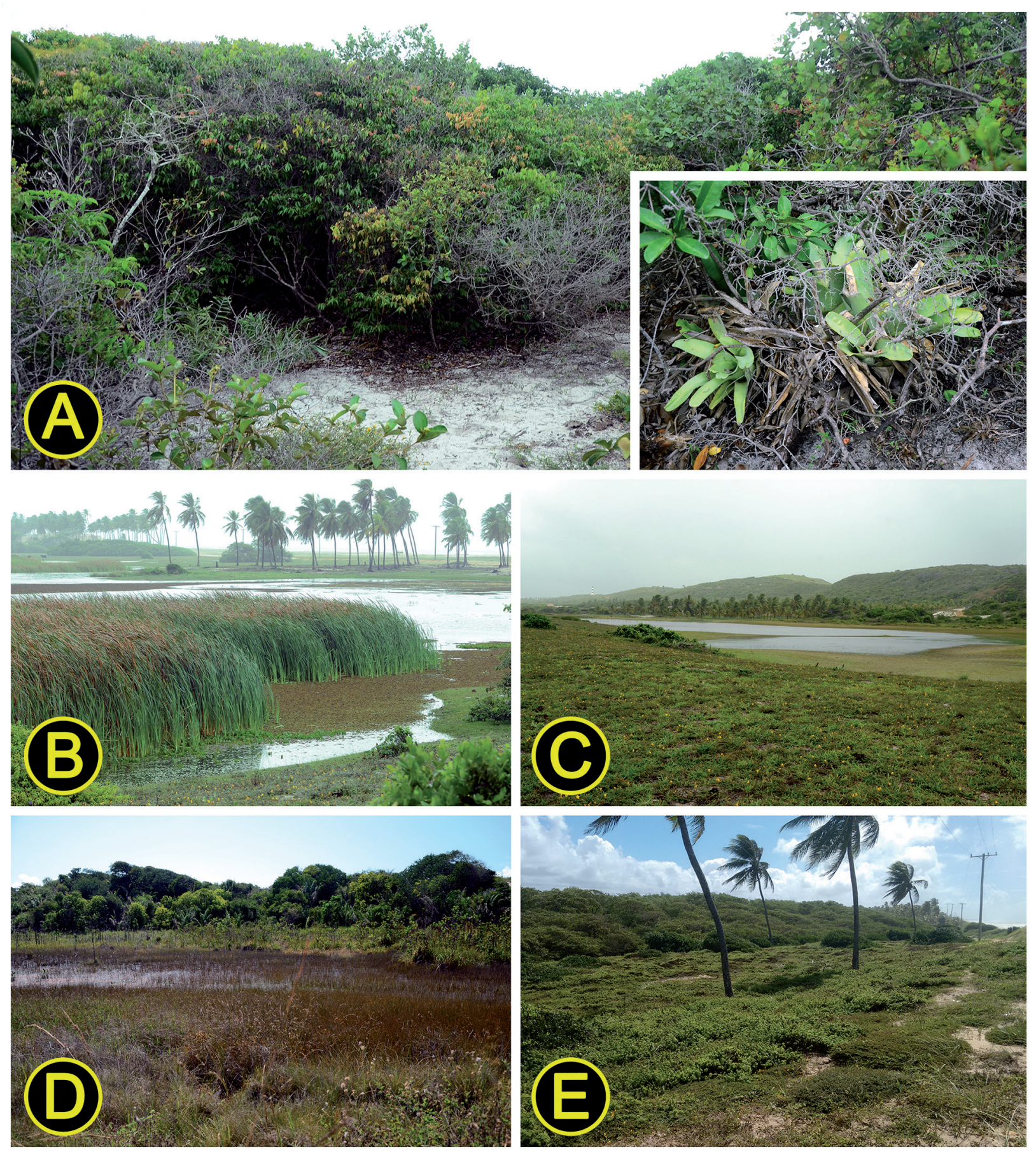

Figure 2. Landscapes in the Restinga of the Conde municipality, northern coast of the state of Bahia, northeastern Brazil, in which the sample units (SUs) and extra sample plots (EPs) were placed. (A) P1, a typical shrub zone, characterized by sandy soil covered by many shrubs and herbaceous vegetation; in detail at the bottom right corner terrestrial bromeliads, the main source of water and shelter for anuran species in shrubby vegetation zones; (B) P5, a marsh with reeds at its margins providing vegetal stratification; (C) P4, a freshwater wetland without vegetal stratification at its borders, characterized as a temporary pond on sandy soil the surroundings of which were covered by grasses; (D) P13, southernmost SU of the study area, placed at freshwater wetlands near forest remnants; (E) EP3, frontal dune near the northern coastal limits of the Conde municipality, featuring the shrub vegetation at the top of the image. Photographs: R.O. Abreu, 16 May 2015.

To obtain species composition, richness and abundance we sampled anuran species using only active search. We looked for anurans in each SU for $20 \mathrm{~min}$ a day, from 18:00 to 23:00 h, over five consecutive nights per campaign, totaling $500 \mathrm{~min}$ of active search per SU per field campaign. We covered each SU with homogeneous effort (i.e., without directing effort to a certain species or only vocalizing species) with a team of five researchers. All observers surveyed simultaneously each SU and the sequences of visitation to SUs were changed randomly during the sampling period. This procedure was performed in all campaigns for the 14 SUs, totaling 233 hours of sampling effort considering the four campaigns. 
Table 1. Sample units (SUs: P1-P14) and extra sample plots (EP1-EP5) used in the survey of anurans at the Restinga of the Conde municipality, northern coast of the state of Bahia, northeastern Brazil (Figure 1). Geographical coordinates in degrees, minutes and seconds, based on the WGS84 datum. Restinga physiognomies: FWZ, freshwater wetland zones; SVZ, shrubby vegetation zones.

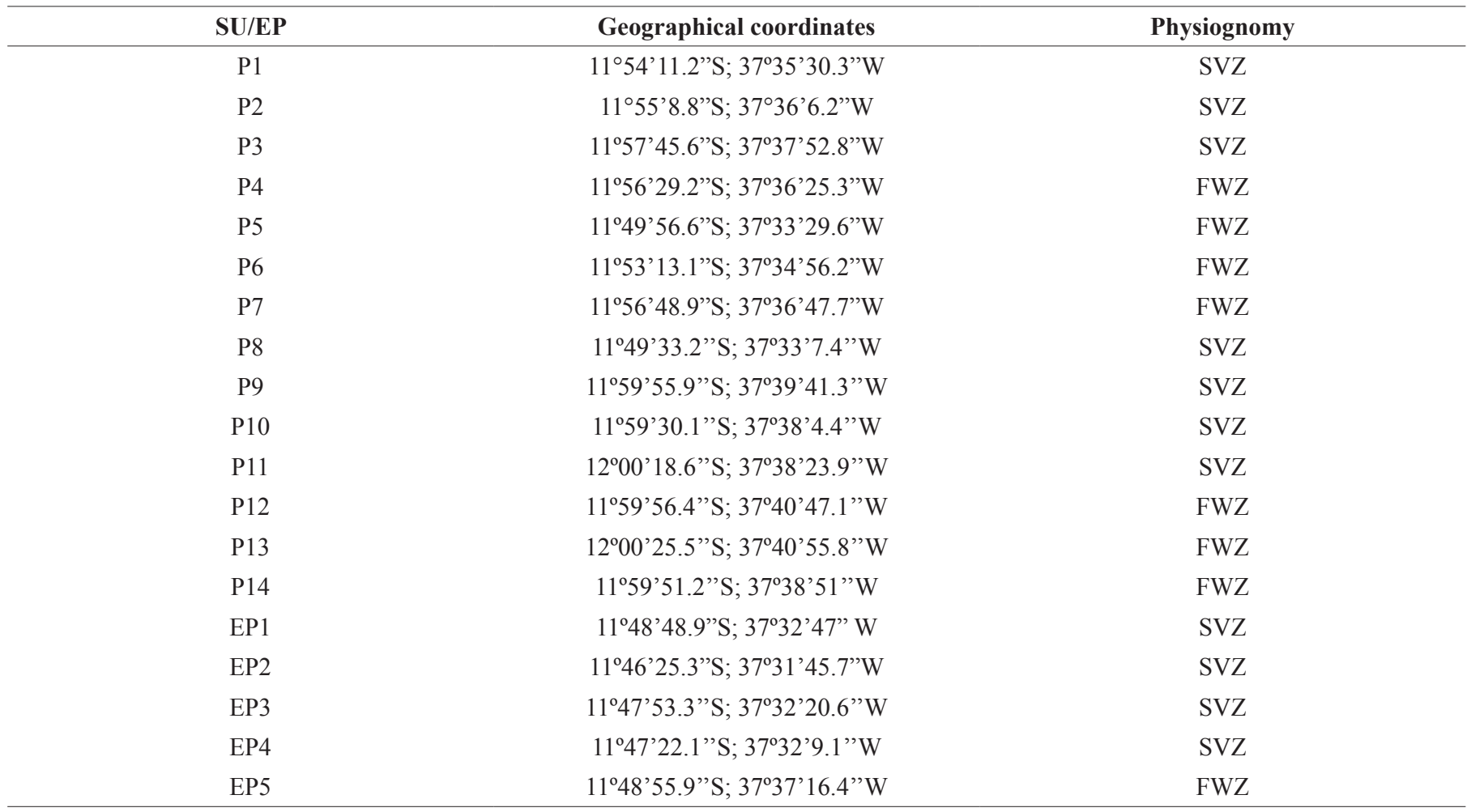

Voucher specimens $(n=187)$ were collected and deposited in the Amphibian Collection of the Museu de Zoologia da Universidade Federal da Bahia (UFBA; Appendix 1), respecting the maximum number of individuals per species allowed by the collection license issued by the Instituto Brasileiro do Meio Ambiente e dos Recursos Naturais Renováveis (IBAMA). Specimens exceeding this maximum number were returned to nature after the sampling period was over in the same SUs where they were collected. Identification of the taxa was performed by analyzing the vocalizations and/or comparison with samples from the Museu de Zoologia da Universidade Federal da Bahia. We followed Frost (2015) for taxa nomenclature.

\section{Data Analysis}

For all statistical analyses we only considered anuran specimens captured in SUs. To estimate anuran species richness, we produced sample-based accumulation curves (sensu Gotelli \& Colwell 2001) using 1000 randomizations on the order of samplings. Each night of observation corresponded to a sample, resulting in 70 samples per physiognomy and 140 samples for the overall study area. We used the species richness estimator Jackknife 1 (first order) to determine the expected richness of anurans (Magurran 2004). Both analyses were performed with EstimateS software, v. 9.1.0 (Colwell 2013). Species abundance distributions were analyzed visually through column charts. We used the Berger-Parker index as a measure of dominance (percentage of the most abundant species); the Gaston's quartile criterion to define commonness and rarity (rare species are those that fall in the lower quartile of the species abundance distribution); the Shannon-Wiener index H' to calculate species diversity; and the Pielou's index J' as an evenness measure (Magurran 2004). The latter analyses were performed with Past software, v. 2.15 (Hammer et al. 2001).

\section{Results}

We sampled a total of 713 individuals, distributed in five families (Bufonidae, Craugastoridae, Hylidae, Leptodactylidae and Microhylidae), 13 genera and 33 species (Table 2; Figures 3-6). Almost all species are categorized as Least Concern by the IUCN (2015), except for Scinax cretatus and S. melanodactylus, for which the conservation status has not yet been evaluated. The family Hylidae showed the highest species richness (20 species, $60.6 \%$ ), followed by Leptodactylidae ( 9 species, $27.3 \%$ ). The remaining families combined accounted for $12.1 \%$ of the species richness (4 species). Considering only the SUs, we recorded 690 individuals distributed in five families, 13 genera and 28 species, in which the most abundant species were Scinax fuscomarginatus $(\mathrm{n}=145$ individuals, 21\%), Pseudopaludicola mystacalis $(\mathrm{n}=121,17.5 \%)$, Leptodactylus macrosternum $(\mathrm{n}=66$, 9.5\%) and Pleurodema diplolister $(\mathrm{n}=64,9.2 \%)$. These four species accounted for $57.2 \%$ of the total number of sampled individuals (Figure 7). Three species were represented by one single individual (singletons): Phyllodytes melanomystax, Phyllomedusa bahiana and Trachycephalus atlas. Five species were represented by only two individuals (doubletons): Dermatonotus muelleri, Hypsiboas faber, H. raniceps, Rhinella granulosa and Scinax eurydice. In extra sample plots we recorded five additional hylid species (number of individuals in brackets): Dendropsophus cf. oliveirai (1), D. elegans (1), Phyllomedusa nordestina (18), Physalaemus kroyeri (2) and Trachycephalus mesophaeus (1). Only P. bahiana and T. mesophaeus 
Gondim-Silva, F.A.T. et al

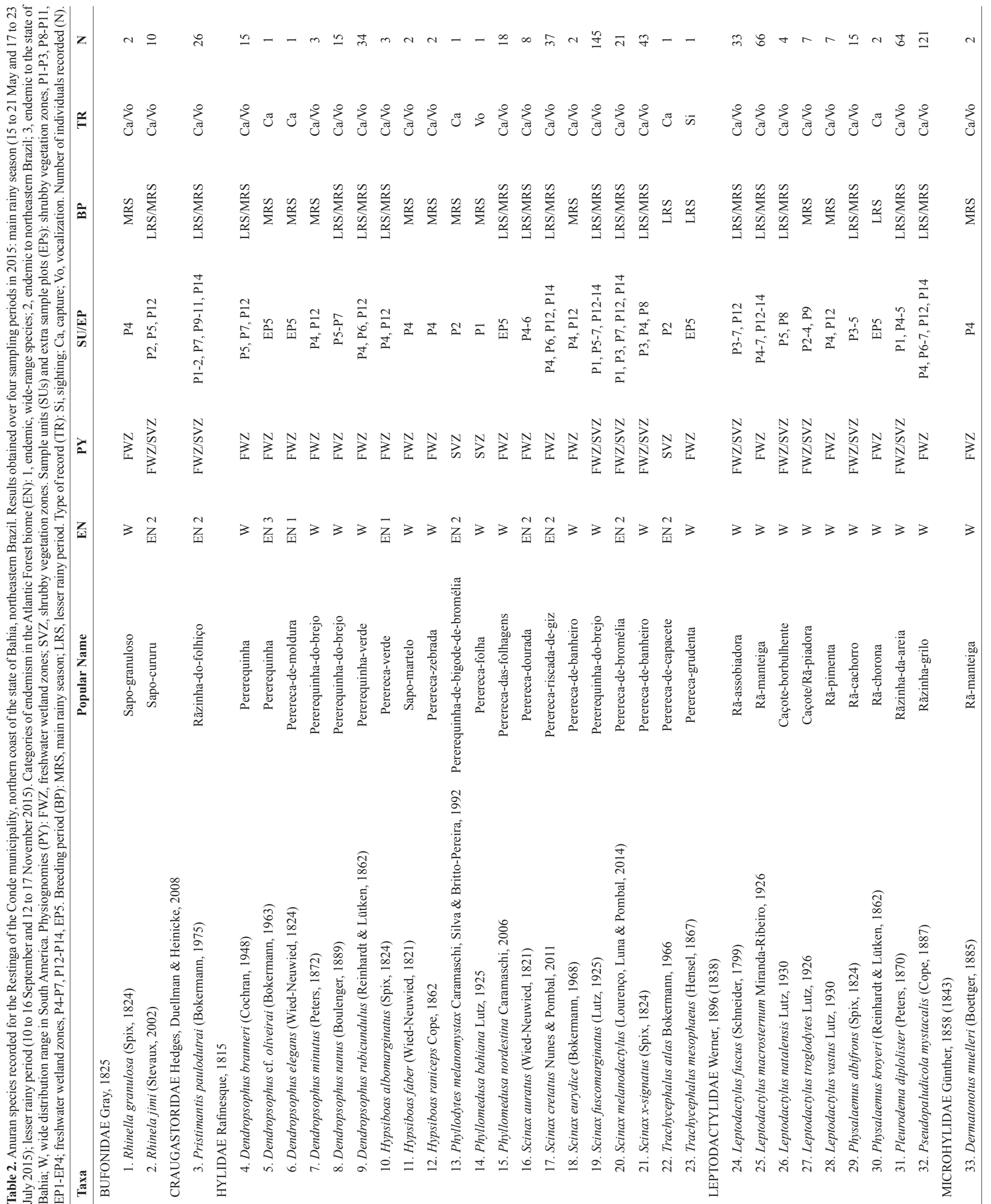



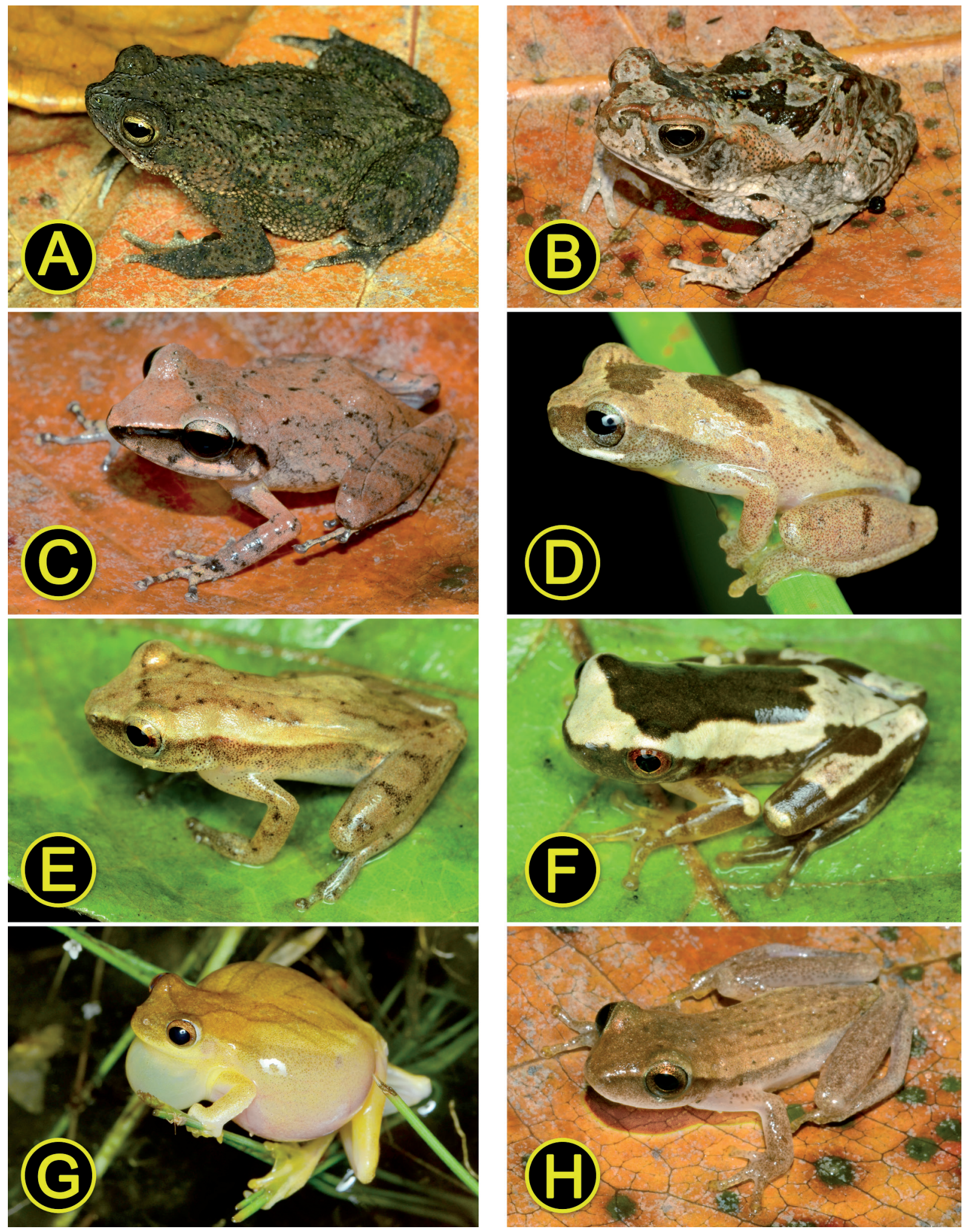

Figure 3. Anurans recorded at the Restinga of the Conde municipality, northern coast of the state of Bahia, northeastern Brazil. In brackets, for each vouchered specimen, is the acronym of the scientific collection followed by the respective institutional registration number and the specimen snout-vent length (SVL) in millimeters. (A) Rhinella granulosa (UFBA 13907; SVL 50.2); (B) Rhinella jimi (UFBA 13961; SVL 33.8); (C) Pristimantis paulodutrai (UFBA 13882; SVL 20.1); (D) Dendropsophus branneri (UFBA 13970; SVL 17.3); (E) D. cf. oliveirai (UFBA 14048; SVL 17.6); (F) D. elegans (UFBA 14044; SVL 12.0); (G) D. minutus (UFBA 13964; SVL 22.3); (H) D. nanus (UFBA 13973; SVL 21.7). Photographs: L. Menezes and R.O. Abreu. 

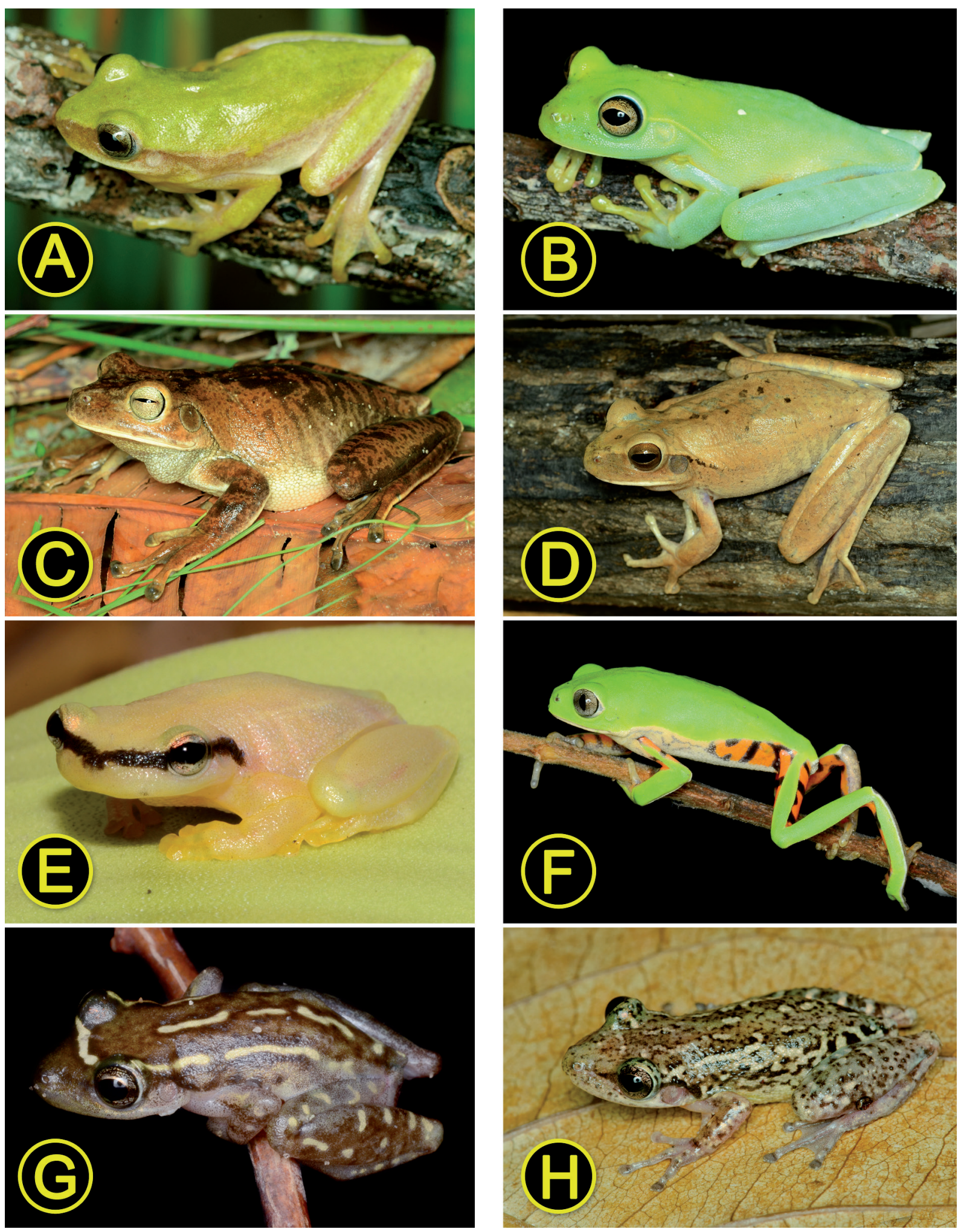

Figure 4. Anurans recorded at the Restinga of the Conde municipality, northern coast of the state of Bahia, northeastern Brazil. See caption of Figure 3 for additional information. (A) Dendropsophus rubicundulus (UFBA 13953; SVL 20.6); (B) Hypsiboas albomarginatus (UFBA 13971; SVL 43.5); (C) H. faber (UFBA 13909; SVL 86.7); (D) H. raniceps (UFBA 13898; SVL 68.6); (E) Phyllodytes melanomystax (UFBA 13960; SVL 23.4); (F) Phyllomedusa nordestina (UFBA 14070; SVL 35.2); (G) Scinax auratus (UFBA 13962; SVL 23.0); (H) Scinax cretatus (UFBA 14036; SVL 30.4). 

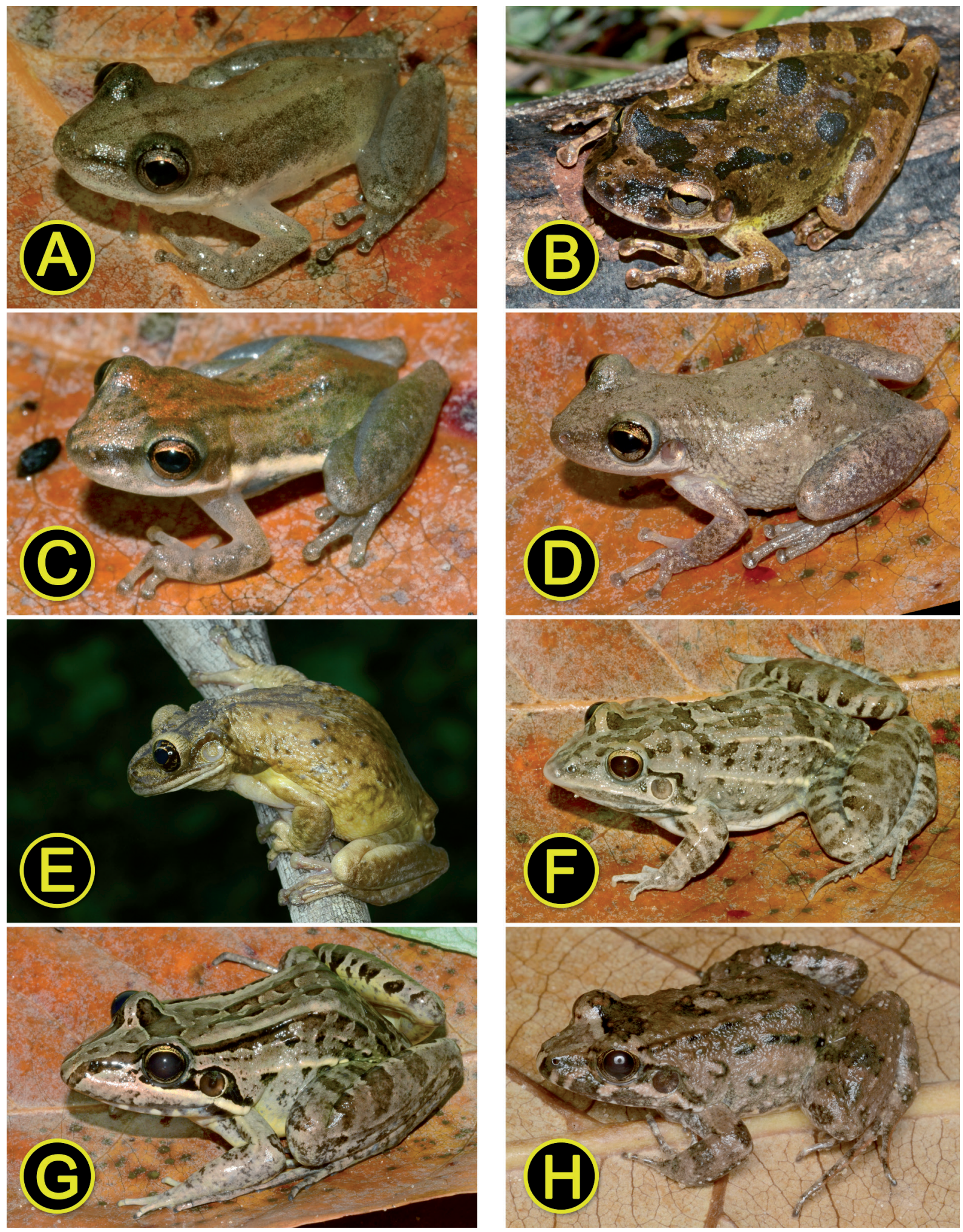

Figure 5. Anurans recorded at the Restinga of the Conde municipality, northern coast of the state of Bahia, northeastern Brazil. See caption of Figure 3 for additional information. (A) Scinax fuscomarginatus (UFBA 14010; SVL 18.6); (B) S. eurydice (UFBA 13893; SVL 42.3); (C) S. melanodactylus (UFBA 13939; SVL 12.4); (D) S. x-signatus (UFBA 13949; SVL 34.1); (E) Trachycephalus atlas (UFBA 14087; SVL 74.4); (F) Leptodactylus fuscus (UFBA 13936; SVL 41.8); (G) L. macrosternum (UFBA 13934; SVL 64.3); (H) L. natalensis (UFBA 13963; SVL 27.3). 

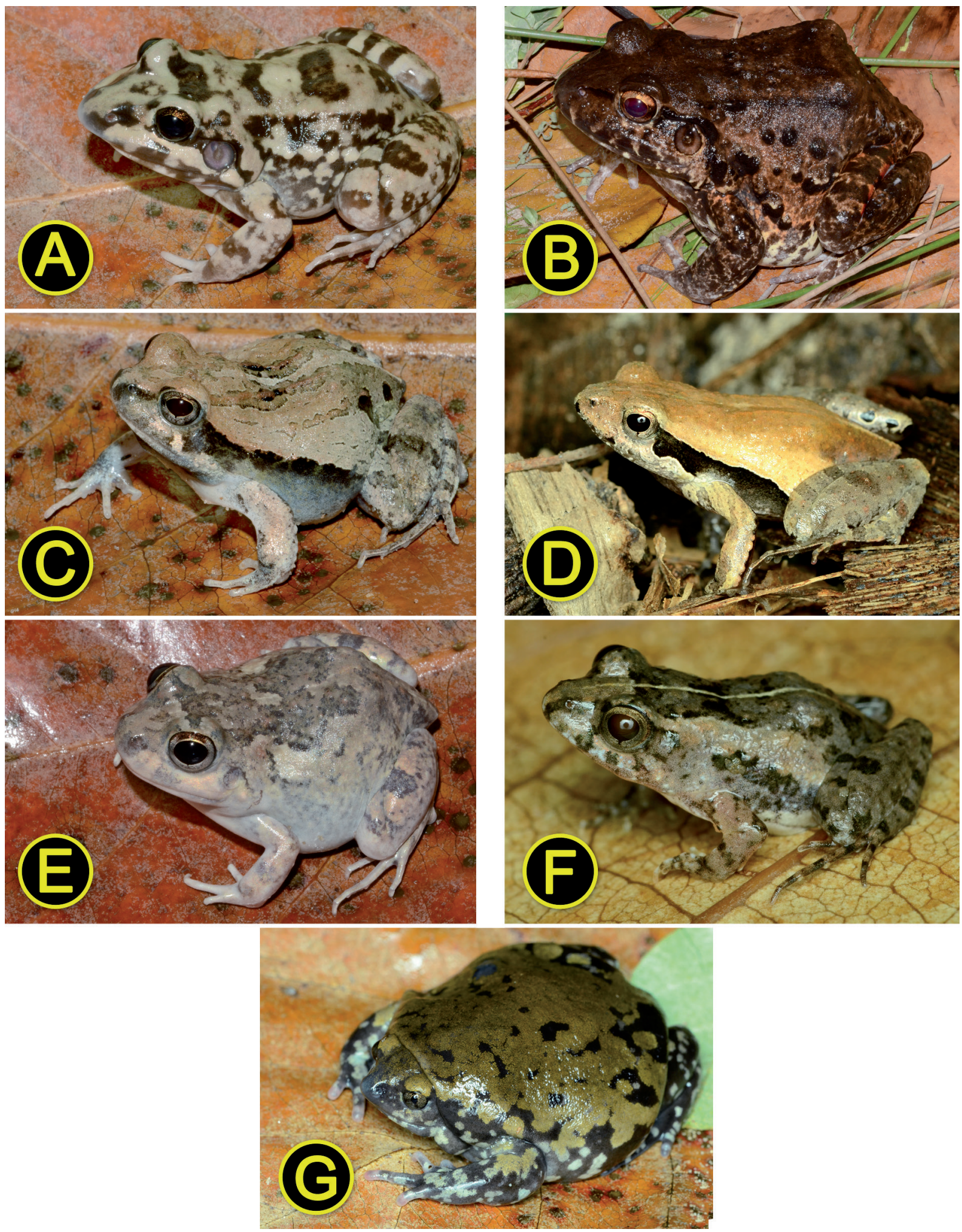

Figure 6. Anurans recorded at the Restinga of the Conde municipality, northern coast of the state of Bahia, northeastern Brazil. See caption of Figure 3 for additional information. (A) Leptodactylus troglodytes (UFBA 13902; 46.6); (B) L. vastus (UFBA 13941; SVL 147.8); (C) Physalaemus albifrons (UFBA 13926; SVL 32.0); (D) P. kroyeri (UFBA 14008; SVL 19.4); (E) Pleurodema diplolister (UFBA 13911; SVL 33.3); (F) Pseudopaludicola mystacalis (UFBA 13955; SVL 11.5); (G) Dermatonotus muelleri (UFBA 13900; SVL 55.2). 
Anurans from the Restinga of Conde
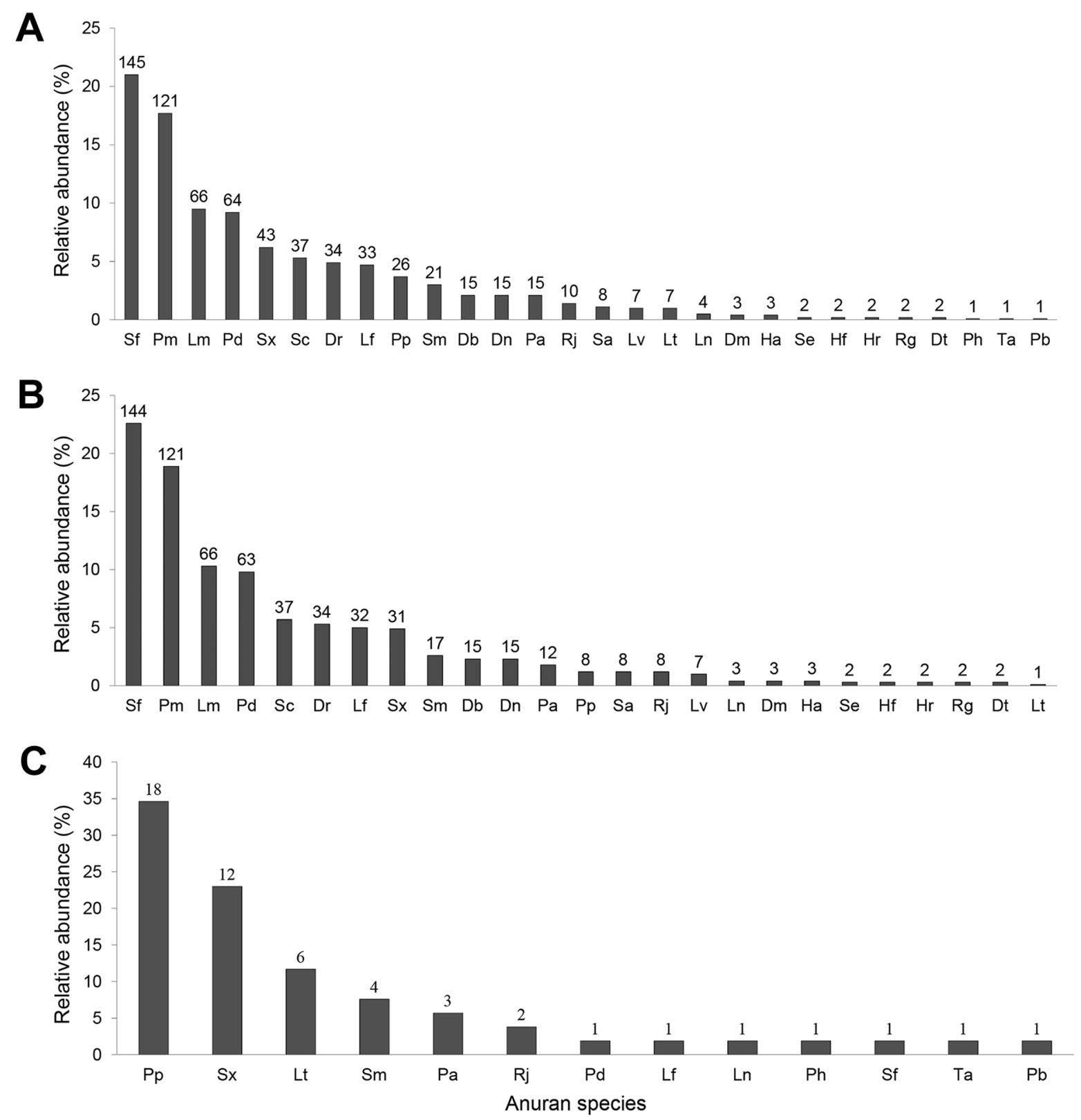

Figure 7. Relative abundance of anuran species (\%) observed at the Restinga of the Conde municipality, northern coast of the state of Bahia, northeastern Brazil. (A) Overall Restinga; (B) wetland zones; (C) shrubby vegetation zones. The total number of recorded individuals per species is indicated above each column. Anuran species: Db, Dendropsophus branneri; Dn, D. nanus; Dm, D. minutus; Dr, D. rubicundulus; Dt, Dermatonotus muelleri; Ha, Hypsiboas albomarginatus; Hf, H. faber; Hr, H. raniceps; Lf, Leptodactylus fuscus; Lm, L. macrosternum; Ln, L. natalensis; Lt, L. troglodytes; Lv, L. vastus; Ph, Phyllodytes melanomystax; Pb, Phyllomedusa bahiana; Pa, Physalaemus albifrons; Pd, Pleurodema diplolister; $\mathrm{Pp}$, Pristimantis paulodutrai; $\mathrm{Pm}$, Pseudopaludicola mystacalis; $\mathrm{Rg}$, Rhinella granulosa; $\mathrm{Rj}$, R. jimi; $\mathrm{Sa}$, Scinax auratus; $\mathrm{Sc}$, S. cretatus; Se, S. eurydice; Sf, S. fuscomarginatus; Sm, S. melanodactylus; Sx, S. x-signatus; Ta, Trachycephalus atlas.

were not vouchered. The specimen identified here as $D$. oliveirai was putatively attributed to this species because it also resembles $D$. decipiens and D. minusculus. These species are highly polymorphic to external morphology and color patterns (Zina et al. 2014) and their specific limits remain unclear.

The species accumulation curves tended to asymptotes for FWZ and the overall study area, but not for SVZ (Figure 8), which suggests that not all anuran species that potentially inhabit the latter physiognomy were recorded. The species richness estimator Jackknife 1 estimated 33.9 \pm 2.3 anuran species for the overall study area 28 species observed in SUs; 33 species combining SUs and EPs], $28.9 \pm 1.9$ species to FWZ (25 species observed in SUs; 30 species combining SUs and EPs) and $20.8 \pm 2.9$ species for SVZ (13 species observed both in SUs and SUs plus EPs). See Table 3 for additional diversity data. 

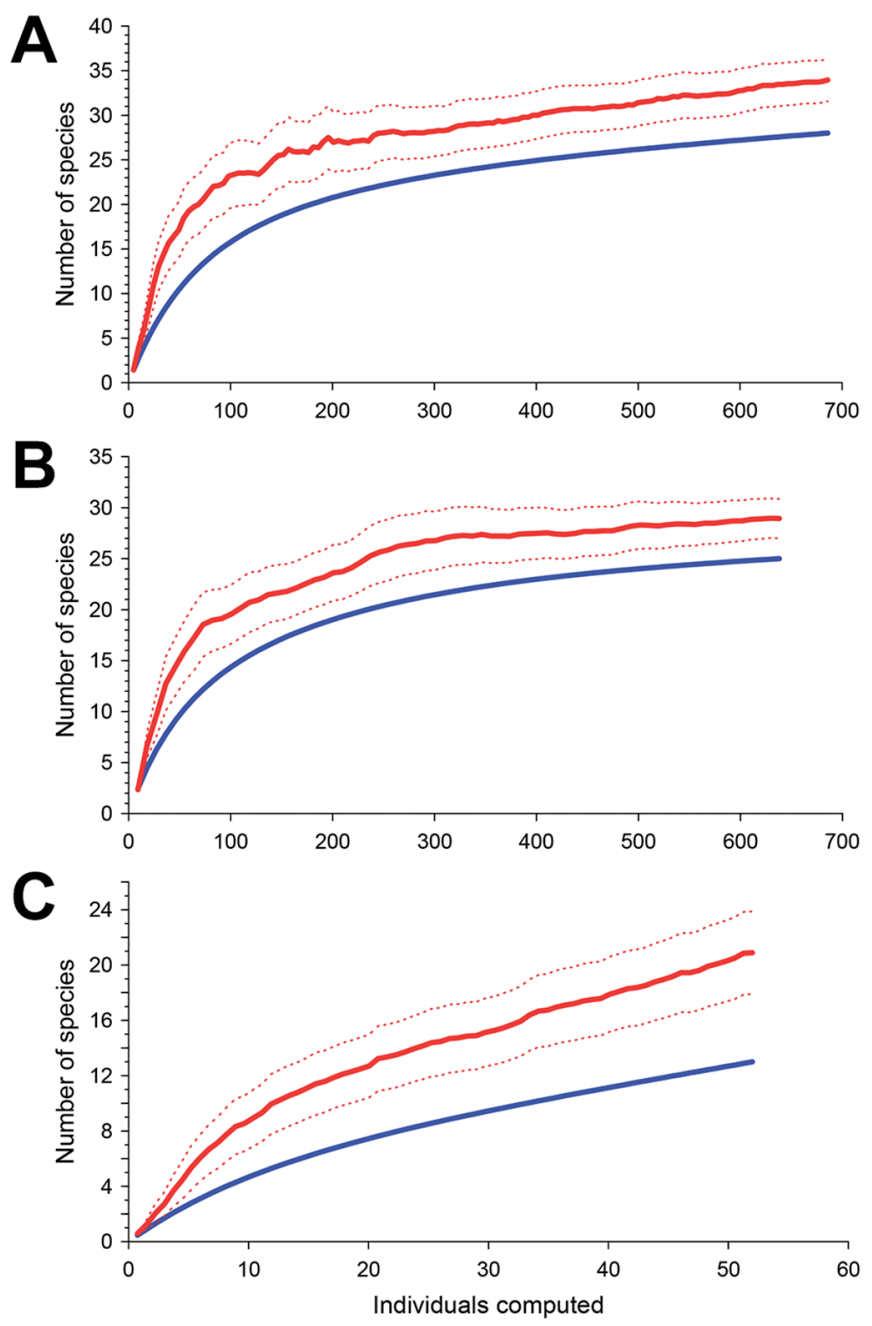

Figure 8. Accumulation curves for anurans sampled at the Restinga of the Conde municipality, northern coast of the state of Bahia, northeastern Brazil, constructed from 1000 randomizations on the order of samplings. (A) Overall Restinga; (B) freshwater wetland zones only; and (C) shrubby vegetation zones only. Blue line represents accumulation curves, red line represents species estimates based on Jackknife 1 estimator and red dashed lines represents its interval of confidence.

The FWZ showed the highest species richness among the sampled environments (25 species, 89.3\%) and SVZ the lowest (13 species; 46.4\%) (Table 3). The family Hylidae had the highest species richness in both physiognomies, followed by Leptodactylidae: FWZ (14 species and eight species, respectively); SVZ (six species and five species, respectively). Regarding species abundances, the highest value was observed for the FWZ (638 individuals, 92.4\%) and the lowest for SVZ (52 individuals, 7.5\%). Ten species were common to both physiognomies: Leptodactylus fuscus, L. natalensis, L. troglodytes, Physalaemus albifrons, Pleurodema diplolister, Pristimantis paulodutrai, Rhinella jimi, Scinax fuscomarginatus, S. melanodactylus and $S$. $x$-signatus. The highest species diversity was obtained for FWZ $\left(H^{\prime}=2.4\right)$ and the lowest for SVZ $\left(H^{\prime}=1.9\right)$, although the evenness was equal for both physiognomies $\left(\mathrm{J}^{\prime}=0.76\right)$.

The species dominance pattern (evenness) was similar for both physiognomies and for the overall study area (Table 3; Figure 7). The same dominant species were observed for the FWZ and overall study area, but not for the SVZ that had a distinct dominant species, indicating that the former contributed more toward the dominance of the overall study area than the latter. In the FWZ, the dominant species was Scinax fuscomarginatus (144 individuals, 22.6\%) and in the SVZ, Pristimantis paulodutrai (18 individuals, 34.6\%). Using the Gaston's criterion for species commonness and rarity, in the overall study area eight species were considered common, 12 species intermediate and eight species rare; in the freshwater wetland zones, eight species were common, eight species intermediate and nine species rare; and in the shrubby vegetation zones, four were common, two were intermediate and seven were rare. There were exclusive species to each physiognomy: FWZ - Dendropsophus branneri, D. minutus, D. nanus, D. rubicundulus, Dermatonotus muelleri, Hypsiboas albomarginatus, $H$. faber, $H$. raniceps, Leptodactylus macrosternum, L. vastus, Pseudopaludicola mystacalis, Rhinella granulosa, Scinax auratus, S. cretatus and $S$. eurydice; SVZ - Phyllodytes melanomystax, Phyllomedusa bahiana and Trachycephalus atlas.

\section{Discussion}

The Restinga of the Conde municipality in the state of Bahia, Brazil, stands out as the second locality with the highest anuran species richness recorded for a Restinga environment (33 species), whereas the highest (34 species) was obtained for the Restinga of the Mata de São João municipality (Bastazini et al. 2007; Telles et al. 2012, Oliveira \& Rocha 2015, Xavier et al. 2015), both of them located in the northern coast (NC) of the state of Bahia. Currently, 62 nominal species of amphibians are known for the NC (M.F. Napoli, L.M. Silva and R.O. Abreu, unpublished data), 60 species of Anura [including an exotic species, Lithobates catesbeianus (Shaw, 1802)] and two species of Gymnophiona [Chthonerpeton noctinectes da Silva, Britto-Pereira \& Caramaschi, 2003 and Siphonops annulatus (Mikan, 1820)]. Of the 60 anuran species listed by M.F. Napoli, L.M. Silva and R.O. Abreu

Table 3. Anuran diversity of the Restinga of the Conde municipality, northern coast of the state of Bahia, northeastern Brazil. Physiognomies: FWZ, freshwater wetland zones; SVZ, shrubby vegetation zones.

\begin{tabular}{lccc}
\hline & Overall Restinga & SVZ & FWZ \\
\hline Number of individuals & 690 & 52 & 638 \\
Species richness (observed) & 28 & 13 & 25 \\
Species richness (Jackknife 1) & $33.9 \pm 2.3$ & $20.8 \pm 2.9$ & $28.9 \pm 1.9$ \\
Dominant species & Scinax fuscomarginatus & Pristimantis paulodutrai & Scinax fuscomarginatus \\
Dominance observed & $21 \%$ & $34.6 \%$ & $22.6 \%$ \\
Shannon-Wiener index (H') & 2.57 & 1.9 & 2.4 \\
Pielou's index J' (evenness) & 0.77 & 0.76 & 0.76 \\
\hline
\end{tabular}


(op. cit.), 33 species (not exotic) were recorded for the 'open Restinga' of the Conde municipality, totaling $55 \%$ of the nominal species recorded for the NC. Previous studies conducted in the NC at the Mata de São João municipality (Juncá 2006, Bastazini et al. 2007) obtained similar anuran species richness (25 and 34 species, respectively). Nonetheless, Juncá (2006) sampled only forested environments at the Reserva Sapiranga and Bastazini et al. (2007) sampled the same habitats used by Juncá (2006) plus the riparian forest of the Timeantube River and shrub vegetation zones at Praia do Forte. As our study considered only shrubby vegetation zones and freshwater wetland zones of 'open' areas, the previous results do not permit direct comparisons with ours, with the exception of the study by Bastazini et al. (2007) for Praia do Forte.

In the Restinga of the Conde municipality we recorded 20 anuran species not registered for the Restinga of Praia do Forte (but six of them were registered at the Reserva Sapiranga), 12 species were common to both Restingas and two species were unique to Praia do Forte [but restricted to the riparian forest, Chiasmocleis sp. and Itapotihyla langsdorffii (Duméril \& Bibron, 1841)]. Although this result represents $57.6 \%$ more anuran species for the Restinga of the Conde municipality, it should be analyzed with caution, because (i) the total extension area analyzed by Bastazini et al. (2007) at Praia do Forte was smaller than that considered in the present study, (ii) these authors did not emphasize the water bodies of the region and (iii) the exclusive species recorded at the Restinga of the Conde municipality are common species in the wetlands of the NC (M.F. Napoli, L.M. Silva and R.O. Abreu, unpublished data), which are likely to disperse throughout the contiguous coastal plains separating these two areas of study.

At the study area, the highest anuran species richness and diversity were observed in wetlands. The presence of water bodies is preponderant in determining species richness (Babbitt \& Tanner 2000) and marshes with reeds also provide vertical substrates that increase the amount of microenvironments available to anurans (Ehrlich 1993, Stiling 1996). The lowest species richness was observed in the shrubby vegetation zones, which is an understandable consequence, considering that these environments have low water availability, a limiting factor for the occurrence of amphibians that depend on it for their osmotic balance and/or as breeding sites (Duellman \& Trueb 1994). On the other hand, the accumulation curve obtained for the shrubby vegetation zones with the Jackknife 1 estimator did not reach an asymptote and estimated a higher species richness than that actually observed (estimated $20.8 \pm$ 2.9 species, observed 13 species). This result is possibly due to the uniques and singletons found in the shrubby vegetation zones that did not decrease with increasing sampling effort, as discussed by Toti et al. (2000). Furthermore, it is noteworthy that three of these singletons were common species in wetlands ( $S$. fuscomarginatus, Pleurodema diplolister and Leptodactylus fuscus) and therefore may be eventually using the shrubby vegetation zones.

Although the sampled shrubby vegetation zones lacked water bodies, more complex plant stratification environments, such as bushes, create different microenvironments, decrease the incidence of direct sunlight and favor the formation of wetter soils by organic matter accumulation, providing humidity and temperatures appropriate to maintain greater diversity of anurans than those areas devoid of vegetation stratification (Xavier \& Napoli 2011). Furthermore, some SUs in shrubby vegetation zones had terrestrial tank bromeliads (Figure 2A), plants that retain moisture between their leaves and accumulate water inside the leaf-tank (Freitas et al. 2000, Cogliatti-Carvalho 2001). In shrubby vegetation zones, terrestrial tank bromeliads are the only source of water supply to maintain the minimum physiological needs of anurans (Dabés et al. 2012) and are considered fundamental ecological units in the Restinga ecosystem since they are used by many wildlife groups for shelter and/or as breeding sites (Peixoto 1995, Richardson 1999, Carvalho-e-Silva et al. 2000, Schneider \& Teixeira 2001, Teixeira et al. 2002). The phytotelm-dweller hylids Phyllodytes melanomystax and Trachycephalus atlas were exclusively observed in these bromeliads, although as singletons. Trachycephalus atlas uses temporary puddles to oviposition and for the development of its tadpoles (Barreto et al. 2015), and therefore the presence of an adult specimen in a bromeliad of the shrubby vegetation zone is possibly associated with its use as shelter. Phyllodytes melanomystax, on the other hand, is a bromeligenous treefrog (sensu Peixoto 1995), i.e. it uses bromeliads throughout its life cycle for breeding and feeding, which explains its restriction to tank bromeliads of this physiognomy. Bastazini et al. (2007) indicated that terrestrial tank bromeliads were among the environmental variables that explained most of the changes in the anuran composition from the Restinga of the Mata de São João municipality. Moreover, $P$. melanomystax was the most frequent species in terrestrial tank bromeliads at Praia do Forte.

The family Hylidae showed the highest species richness in the Restinga of the Conde municipality, which coincides with the pattern already reported for the Restinga of the Mata de São João municipality (Juncá 2006, Bastazini et al. 2007) and for other Restingas in Brazil (e.g., Rocha et al. 2008, Narvaes et al. 2009, Zina et al. 2012, Oliveira \& Rocha 2015). In the wetland zones, the dominant species was Scinax fuscomarginatus (Table 3). This small-sized hylid is commonly associated with reeds and other emergent plants in temporary ponds and lagoons (Brasileiro et al. 2005, Van-Silva et al. 2007, Serafim et al., 2008), similar to those observed in the wetlands of the study area (Figure 2B, D), except for the SU P4. This SU differed from the others by not showing plant stratification, being essentially characterized as a temporary pond in sandy soil the surroundings of which were covered by grasses (Figure 2C). The dominant anuran species at $\mathrm{P} 4$ was the leptodactylid Pseudopaludicola mystacalis, a small-sized terrestrial and semiaquatic species that is abundant in wetlands of opens formations (Silva et al. 2008, Ribeiro-Junior \& Bertoluci 2009, Valdujo et al. 2011). In shrubby vegetation zones the dominant species was a Terrarana, the craugastorid Pristimantis paulodutrai, the most abundant species in forested areas of the NC (Bastazini et al. 2007). Pristimantis paulodutrai is a small-sized direct-developing frog with terrestrial breeding (Napoli et al. 2009), like other Terrarana (Hedges et al. 2008). This mode of reproduction allows this species to breed in environments deprived of water bodies (Xavier \& Napoli 2011). Furthermore, P. paulodutrai has a low dehydration rate and high rate of rehydration from a neutral substrate (Dabés et al. 2012), which helps to explain its ability to occupy different types of environments, including those under high osmotic stress, as is the case of shrubby vegetation zones.

The species composition observed for the Restinga of the Conde municipality deserves additional comments. The Restingas of northeastern Brazil were singled out by Xavier et al. (2015) as a unique biotic element with respect to ecological and biogeographic distribution of anuran species, including taxa from three distinct morphoclimatic domains (Tropical Atlantic, Cerrado and Caatinga). 
These authors considered eight anuran species from that biotic element as exclusive to the Atlantic Tropical domain, six (75\%) of which were recorded in this study: Leptodactylus vastus, Phyllodytes melanomystax, Pristimantis paulodutrai, Scinax auratus, S. cretatus and S. eurydice. Seven species were common to the Cerrado and Caatinga domains, all recorded in the Restinga of the Conde municipality: Dendropsophus nanus, D. rubicundulus, Dermatonotus muelleri, Hypsiboas raniceps, Leptodactylus troglodytes, Pleurodema diplolister and Rhinella jimi. These authors also highlighted the existence of small and sparse relictual patches of Cerrado and Caatinga in the $\mathrm{NC}$, some of them contiguous with Restinga environments, which could explain the presence of anuran species from three different morphoclimatic domains (see Xavier et al. 2015 for the discussion on the possible relationship between these relictual patches of Cerrado and Caatinga habitats and climatic fluctuations of the last period of the Quaternary).

The Restinga of the Conde municipality contains $87 \%$ of the anuran species found in the northeastern biotic element studied by Xavier et al. (2015), a natural biogeographical unit. Natural biogeographical units are basic units of comparison in many ecological and evolutionary large-scale studies and are areas that should be evaluated when planning the conservation of biota, once they allow the understanding of both the evolutionary history of taxa and areas (Lomolino et al. 2006, Xavier et al. 2015). Moreover, the Restinga of the Conde municipality stands out as the one with the highest anuran species richness already recorded considering only shrubby vegetation zones and freshwater wetland zones. In this context, the Restinga of the Conde municipality seems to be an important region for the conservation of the biota of the northern coast of the state of Bahia.

\section{Appendix 1}

Vouchers of anurans collected at the Restinga of the Conde municipality, northern coast of the state of Bahia, northeastern Brazil. The data were entered in the following order: family, species, acronym of the scientific collection (UFBA, Museu de Zoologia da Universidade Federal da Bahia) followed by their institutional record number (Arabic numerals).

BUFONIDAE. Rhinella granulosa, UFBA 13907-13908. Rhinella jimi, UFBA 13961.

CRAUGASTORIDAE. Pristimantis paulodutrai, UFBA 1388213891, 14067-14069.

HYLIDAE. Dendropsophus branneri, UFBA 13970, 14056-14058. Dendropsophus oliveirai, UFBA 14048. Dendropsophus elegans, UFBA 14044. Dendropsophus minutus, UFBA 13964-13965, 14049. Dendropsophus nanus, UFBA 13972-13984, 14064. Dendropsophus rubicundulus, UFBA 13953-13954, 14051-14055, 14065-14066. Hypsiboas albomarginatus, UFBA 13971, 14047. Hypsiboas faber, UFBA 13909-13910. Hypsiboas raniceps, UFBA 13898-13899. Phyllodytes melanomystax, UFBA 13960. Phyllomedusa nordestina, UFBA 13985-13999, 14001-14003, 14070. Scinax auratus, UFBA 13962 , 13966-13969. Scinax cretatus, UFBA 14037-14043. Scinax eurydice, UFBA 13893, 14050. Scinax fuscomarginatus, UFBA 14010-14025. Scinax melanodactylus, UFBA 13939-13940, 14034. Scinax x-signatus, UFBA 13892, 13942-13952. Trachycephalus atlas, UFBA 14087.
LEPTODACTYLIDAE. Leptodactylus fuscus, UFBA 13936-13938, 13897, 14061-14063. Leptodactylus macrosternum, UFBA $13934-$ 13935, 13894-13896, 14060. Leptodactylus natalensis, UFBA 13963. Leptodactylus troglodytes, UFBA 13902-13906, 14035. Leptodactylus vastus, UFBA 13941, 14045-14046. Physalaemus albifrons, UFBA 13926-13933. Physalaemus kroyeri, UFBA 14008-14009. Pleurodema diplolister, UFBA 13911-13925. Pseudopaludicola mystacalis, UFBA 13955-13958, 14059.

MICROHYLIDAE. Dermatonotus muelleri, UFBA 13900-13901.

\section{Acknowledgments}

We are grateful to Marcelo Alves Dias (UCSal), Marcelo César Lima Peres (UCSal) and Thais Andrade Ferreira Dória (IFBaiano) for the valuable comments on the first draft of the manuscript; to Clara Ribeiro Porto (UFBA) for logistical assistance at the Conde municipality. M.F. Napoli acknowledges the Rede Baiana de Pesquisa sobre Anfíbios (RBPA) for financial support under the research project "Padrões e processos da diversidade de anfíbios na Bahia: influência das mudanças climáticas e propostas de conservação", supported by the Fundação de Amparo à Pesquisa do Estado da Bahia (FAPESB) and the Secretaria do Meio Ambiente da Bahia (SEMA) (PAM0005/2014); the Conselho Nacional de Desenvolvimento Científico e Tecnológico (CNPq) for the research productivity grants (Proc. 309672/2012-0 and 305849/2015-8); and the Instituto Brasileiro do Meio Ambiente e dos Recursos Naturais Renováveis (IBAMA) and Instituto Chico Mendes de Conservação da Biodiversidade (ICMBio) for permission to collect anuran specimens (license 12988-1). C.C. Trevisan thanks the FAPESB for master's fellowship (grant BOL3531/2014). F.A.T. Gondim-Silva thanks the Institutional Scientific Initiation Scholarship Program (UFBA/PIBIC/ CNPq) for undergraduate scholarship (Proc. 151251/2015-0).

\section{References}

AB'SÁBER, A.N. 1977. Os domínios morfoclimáticos na América do Sul. Primeira aproximação. Geomorfologia 52: 1-20.

ALVARES, C.A., STAPE, J.L., SENTElHAS, P.C., GONÇALVES, J.L.M. \& SPAROVEK, G. 2013. Köppen's climate classification map for Brazil. Meteorologische Zeitschrift 22(6): 711-728, http://dx.doi.org/10.1127/09412948/2013/0507.

ARAÚJO, D.S.D. 1992. Vegetation types of sand coastal plains of Tropical Brazil: a first approximation. In Coastal plant communities of Latin America (U. Seeliger, ed.). Academic Press, San Diego, p.337-347.

BABBITT, K.J. \& TANNER, G.W. 2000. Use of temporary wetlands by anurans in a hydrologically modified landscape. Wetlands 20(2): 313-322, http:// dx.doi.org/10.1672/0277-5212(2000)020\%5B0313:UOTWBA\%5D2.0. $\mathrm{CO} ; 2$.

BARRETO, G.S., RAMOS, J.C., MERCES, E.D.A., NAPOLI, M.F., GARDA, A.A. \& JUNCÁ, F.A. 2015. External morphology and oral cavity of the tadpole of Trachycephalus atlas Bokermann, 1966 (Amphibia, Anura, Hylidae). Zootaxa 3980(4): 597-600, http://dx.doi.org/10.11646/ zootaxa.3980.4.10.

BASTAZINI, C.V., MUNDURUCA, J.F.V., ROCHA, P.L.B. \& NAPOLI, M.F. 2007. Which environmental variables better explain changes in anuran community composition? A case study in the restinga of Mata de São João, Bahia, Brazil. Herpetologica 63(4): 459-471, http://dx.doi. org/10.1655/0018-0831(2007)63[459:WEVBEC]2.0.CO;2. 
BITTENCOURT, A.C.S.P., LIVRAMENTO, F.C., DOMINGUEZ, J.M.L. \& SILVA, I.R. 2010. Tendência de longo prazo à erosão costeira num cenário perspectivo de ocupação humana: litoral norte do estado da Bahia. Revista Brasileira de Geociências 40(1): 125-137. https://repositorio.ufba. br/ri/bitstream/ri/2709/1/14592-72008-1-PB.pdf (last access at 31/12/2015).

BRASILEIRO, C.A., SAWAYA, R.J., KIEFER, M.C. \& MARTINS, M. 2005. Amphibians of an open Cerrado fragment in southeastern Brazil. Biota Neotropica 5(2): 93-109. http://www.biotaneotropica.org.br/v5n2/pt/ abstract?article+BN00405022005 (last access at 31/12/2015).

CARVALHO-E-SILVA, S.P., IZECKSOHN, E. \& CARVALHO-E-SILVA, A.M.P.T. 2000. Diversidade e ecologia de anfíbios em restingas do sudeste brasileiro. In Ecologia de restingas e lagoas costeiras (F.A. Esteves \& L.D. Lacerda, eds). NUPEM/UFRJ, Macaé, p.89-97.

COGLIATTI-CARVALHO, L., FREITAS, A.F.N., ROCHA, C.F.D. \& VAN SLUYS, M. 2001. Variação na composição de Bromeliaceae em cinco zonas de vegetação de restinga no Parque Nacional da Restinga de Jurubatiba, Macaé, RJ. Revista Brasileira de Botânica 24(1): 1-9. http://www.scielo. $\mathrm{br} / \mathrm{pdf} / \mathrm{rbb} / \mathrm{v} 24 \mathrm{n} 1 / \mathrm{a} 01 \mathrm{v} 24 \mathrm{n} 1 . \mathrm{pdf}$ (last access at 31/12/2015).

COLWELL, R.K. 2013. EstimateS, Version 9.1: Statistical Estimation of Species Richness and Shared Species from Samples (Software and User's Guide) http://viceroy.eeb.uconn.edu/estimates/EstimateSPages/EstSUsersGuide/ EstimateSUsersGuide.htm (last access at 31/12/2015).

DABÉS, L., BONFIM, V., NAPOLI, M.F. \& KLEIN, W. 2012. Water balance and spatial distribution of an anuran community from Brazil. Herpetologica 68: 443-455, http://dx.doi.org/10.1655/HERPETOLOGICA-D-10-00058.

DOMINGUEZ, J.M.L., MARTIN, L., BITTENCOURT, A.C.S.P., TESTA, V., LEÃO, Z.M.A.N. \& SILVA, C.C. 1999. Atlas Geoambiental da Zona Costeira do Estado da Bahia - Conde. UFBA/SME, Salvador.

DUELLMAN, W.E. \& TRUEB, L. 1994. Biology of Amphibians. Johns Hopkins University Press, Baltimore.

EHRLICH, P.R. 1993. O mecanismo da natureza: o mundo vivo à nossa volta e como ele funciona. Editora Campus, Rio de Janeiro.

ESQUIVEL, M.S. (2006) O Quaternário costeiro do município de Conde: implicações para a gestão ambiental. Dissertação de Mestrado, Universidade Federal da Bahia, Salvador.

FREIRE, M.S.B. 1990. Levantamento florístico do Parque Estadual das Dunas de Natal. Acta Botanica Brasilica 4(2): 41-59, http://dx.doi.org/10.1590/ S0102-33061990000300006.

FREITAS, A.F.N., COGLIATTI-CARVALHO, L., VAN SLUYS, M. \& ROCHA, C.F.D. 2000. Distribuição espacial de bromélias na restinga de Jurubatiba. Acta Botânica Brasileira 14(2): 175-180. http://dx.doi.org/10.1590/S010233062000000200005.

FROST, D.R. 2015. Amphibian species of the world: an online reference. Version 6.0. Electronic database accessible at http://research.amnh.org/herpetology/ amphibia/index.html. American Museum of Natural History, New York, USA (last access at 31/12/2015).

GOTELLI, N.J. \& COLWELL, R.K. 2001. Quantifying biodiversity: procedures and pitfalls in the measurement and comparison of species richness. Ecology Letters 4(4): 379-391. http://onlinelibrary.wiley.com/doi/10.1046/j.14610248.2001.00230.x/pdf (last access at 31/12/2015).

HAMMER, Ø., HARPER, D.A.T. \& RYAN, P.D. 2001. PAST: Paleontological statistics software package for education and data analysis. Palaeontologia Electronica 4(1): 9. http://palaeo-electronica.org/2001_1/past/past.pdf (last access at 31/12/2015).

HEDGES, S.B., DUELLMAN, W.E. \& HEINICKE, M.P. 2008. New World direct-developing frogs (Anura: Terrarana): molecular phylogeny, classification, biogeography, and conservation. Zootaxa 1737: 1-182.

HURLBERT, S.H. 1984. Pseudoreplication and the design of ecological field experiments. Ecological Monographs 54(2): 187-211.

INEMA - INSTITUTO DO MEIO AMBIENTE E RECURSOS HÍDRICOS 2015. APA Litoral Norte do Estado da Bahia. http://www.inema.ba.gov. $\mathrm{br} / \mathrm{gestao}-2 /$ unidades-de-conservacao/apa/apa-litoral-norte-do-estado-dabahia/ (last access at 31/December/2015).
IUCN 2015. The IUCN Red List of Threatened Species. Version 2015-4. http:// www.iucnredlist.org (last access at 02/01/2016).

JUNCÁ, F.A. 2006. Diversidade e uso de hábitat por anfíbios anuros em duas localidades de Mata Atlântica, no norte do estado da Bahia. Biota Neotropica 6(2): 1-17. http://www.biotaneotropica.org.br/v6n2/pt/ fullpaper?bn03006022006+pt (last access at 31/December/2015).

LOMOLINO, M.V., RIDDLE, B.R. \& BROWN, J.H. 2006. Biogeography. Sinauer Associates, Inc., Sunderland.

MAGURRAN, A.E. 2004. Measuring biological diversity. Blackwell Science, Oxford.

MENEZES, C.M., AGUIAR, L.G.P.A. \& ESPINHEIRA, M.J.C.L. 2009. Florística e fitossociologia do componente arbóreo do município de Conde, Bahia, Brasil. Revista Biociências 15(1): 44-55. http://periodicos.unitau. br/ojs-2.2/index.php/biociencias/article/viewFile/816/632 (last access at 31/December/2015).

MYERS, N., MITTERMEIER, R.A., MITTERMEIER, C.G., FONSECA, G.A.B., KENT, J. (2000) Biodiversity hotspots for conservation priorities. Nature 403: 853-858. http://www.ncbi.nlm.nih.gov/pubmed/10706275 (last access at 31/December/2015).

NAPOLI, M.F., ANANIAS, F., FONSECA, P. \& SILVA, A.P.Z. 2009. Morphological and karyotypic contributions for a better taxonomic definition of the frog Ischnocnema ramagii (Boulenger, 1888) (Anura, Brachycephalidae). South American Journal of Herpetology 4(2): 164-172, http://dx.doi.org/10.2994/057.004.0207.

NARVAES, P., BERTOLUCI, J. \& RODRIGUES, M.T. 2009. Species composition, habitat use and breeding seasons of anurans of the restinga forest of the Estação Ecológica Juréia-Itatins, Southeastern Brazil. Biota Neotropica 9 (2): 117-123. http://www.scielo.br/scielo.php?script=sci arttext\&pid=S1676-06032009000200011\&lng=en\&nrm=iso (last access at 31/12/2015), http://dx.doi.org/10.1590/S1676-06032009000200011.

NOGUEIRA, R.X.S. 2006. Mapeamento dos ecossistemas costeiros e das mudanças na ocupação do solo no município de Conde, litoral norte da Bahia, Brasil: integração de sensoriamento remoto e sig para a gestão costeira. Dissertação de Mestrado, Universidade Federal da Bahia, Salvador

PEIXOTO, O.L. 1995. Associação de anuros a bromeliáceas na mata Atlântica. Revista da Universidade Rural 17(2): 75-83. http://ufrrj.br/SEER/index.ph p?journal=rcv\&page $=$ article\&op $=$ download\&path $\% 5 \mathrm{~B} \% 5 \mathrm{D}=1568 \&$ path $\% 5 \mathrm{~B} \% 5 \mathrm{D}=1113$ (last access at 31/12/2015).

OLIVEIRA, J.C.F. \& ROCHA, C.F.D. 2015. A review on the anurofauna of Brazil's sandy coastal plains. How much do we know about it? Journal of Coastal Conservation 19: 35-49. http://dx.doi.org/10.1007/s11852-0140354-8.

RIBEIRO-JÚNIOR, J.W. \& BERTOLUCI, J. 2009. Anurans of the cerrado of the Estação Ecológica and the Floresta Estadual de Assis, southeastern Brazil. Biota Neotropica 9(1): 207-216. http://www.biotaneotropica.org.br/v9n1/ pt/fullpaper?bn02709012009+pt (last access at 31/12/2015).

RICHARDSON, B.A. 1999. The bromeliad microcosm and the assessment of faunal diversity in a neotropical forest. Biotropica 31:321-336. http://dx.doi org/10.1111/j.1744-7429.1999.tb00144.x.

ROCHA, C.F.D., HATANO, F.H., VRCIBRADIC, D. \& VAN SLUYS, M. 2008. Frog species richness, composition $\beta$-diversity in coastal Brazilian restinga habitats. Brazilian Journal of Biology 68(1): 101-107.

SCHINEIDER, J.A.P. \& TEIXEIRA, R.L. 2001. Relacionamento entre anfíbios anuros e bromélias da restinga de regência, Linhares, Espírito Santo, Brasil. Iheringia, Série Zoologia 91: 41-48. http://dx.doi.org/10.1590/S007347212001000200005 (last access at 31/12/2015).

SEI - SUPERINTENDÊNCIA DE ESTUDOS ECONÔMICOS E SOCIAIS DA BAHIA. 2015. Sistema de informações municipais. http://sim.sei.ba.gov. br/sim/index.wsp (last access at 31/12/2015).

SERAFIM, H., IENNE, S., CICCHI, P.J.P. \& JIM, J. 2008. Anurofauna de remanescentes de floresta Atlântica do município de São José do Barreiro, estado de São Paulo, Brasil. Biota Neotropica 8(2): 69-78. http://www. biotaneotropica.org.br/v8n2/pt/fullpaper?bn01008022008+pt (last access at $31 / 12 / 2015$ ). 
SILVA, R.A., MARTINS, I.A. \& ROSSA-FERES, D.D.C. 2008. Bioacústica e sítio de vocalização em taxocenoses de anuros de área aberta no noroeste paulista. Biota Neotropica 8(3): 123-134. http://www.biotaneotropica.org. br/v8n3/pt/fullpaper?bn01608032008 (last access at 31/12/2015), http:// dx.doi.org/10.1590/S1676-06032008000300012.

SOARES, G.A. \& DOMINGUEZ, J.M.L. 2012. Zonas úmidas na planície costeira do rio Itapicuru, litoral norte do estado da Bahia, Brasil: classificação e controles ambientais. Revista da Gestão Costeira Integrada 12(2): 223-237, http://dx.doi.org/10.5894/rgci324.

STILING, P.D. 1996. Ecology: theories and applications. 2 ed. Prentice Hall Ed., New Jersey.

TEIXEIRA, R.L., SCHINEIDER, J.A.P \& ALMEIDA, G.I. 2002. The occurrence of amphibians in bromeliads from a southeastern Brazilian Restinga habitat, with special reference to Aparasphenodon brunoi (Anura, Hylidae). Brazilian Journal of Biology 62(2): 263-268, http://dx.doi.org/10.1590/ S1519-69842002000200010.

TELLES, F.B.S., MENEZES, V.A., MAIA-CARNEIRO, T., DORIGO, T.A., WINCK, G.R. \& ROCHA, C.F.D. 2012. Anurans from the "Restinga" of Parque Natural Municipal de Grumari, state of Rio de Janeiro, southeastern Brazil. Check List 8(6): 1267-1273. http://www.checklist.org. br/getpdf?SL085-10 (last access at 12/04/2016).

TOTI, D.S., COYLE, F.A. \& MILLER, J.A. 2000. A structured inventory of Appalachian grass bald and heath bald spider assemblages and a test of species richness estimator performance. The Journal of Arachnology 28: 329-345. http://www.americanarachnology.org/JoA_free/JoA_v28_n3/ arac-28-03-0329 (last access at 31/12/2015).
VALDUJO, P.H., CAMACHO, A., RECODER, R.S., JUNIOR, M.T., GHELLERE, J.M.B., MOTT, T. \& RODRIGUES, M.T. 2011. Anfíbios da Estação Ecológica Serra Geral do Tocantins, região do Jalapão, estados do Tocantins e Bahia. Biota Neotropica 11(1): http://www.biotaneotropica.org. br/v11n1/pt/abstract?article+bn03511012011 (last access at 31/12/2015), http://dx.doi.org/10.1590/S1676-06032011000100025.

VAN-SILVA, W., GUEDES, A.G., AZEVEDO-SILVA, P.L., GONTIJO, F.F., BARBOSA, R.S., ALOÍSIO, G.R. \& OLIVEIRA, F.C.G. 2007. Herpetofauna, Espora hydroelectric power plant, state of Goiás, Brazil. Check List 3(4): 338-345. http://www.checklist.org.br/getpdf?SL018-07 (last access at 31/12/2015).

XAVIER, A.L. \& NAPOLI, M.F. 2011. Contribution of environmental variables to anuran community structure in the Caatinga Domain of Brazil. Phyllomedusa 10(1): 45-64. http://www.phyllomedusa.esalq.usp.br/articles/ volume10/number1/1014564.pdf (last access at 31/12/2015).

XAVIER, A.L., GUEDES, T.B. \& NAPOLI, M.F. 2015. Biogeography of anurans from the poorly known and threatened coastal sandplains of eastern Brazil. PloS One 10(6): e0128268. http://journals.plos.org/plosone/ article?id=10.1371/journal.pone.0128268 (last access at 31/12/2015), http:// dx.doi.org/10.1371/journal.pone.0128268.

ZINA, J., PRADO, C.P.A., BRASILEIRO, C.A. \& HADDAD, C.F.B. 2012. Anurans of the sandy coastal plains of the Lagamar Paulista, State of São Paulo, Brazil. Biota Neotropica 12(1): 251-260. http://www.biotaneotropica. org.br/v12n1/en/abstract?inventory+bn02212012012 (last access at 31/12/2015), http://dx.doi.org/10.1590/S1676-06032012000100020.

ZINA, J.A, SILVA, G.R.B, LOEBMANN, D.C \& ORRICO, V.G.D. 2014. The recognition of Dendropsophus minusculus (Rivero, 1971) (Hylidae, Dendropsophini) as a highly polymorphic, multi-domain distributed species. Brazilian Journal of Biology 74(3): S146-S153, http://dx.doi. org/10.1590/1519-6984.22912. 